\title{
Diabetes Mellitus raise the Risk for Interval Colorectal Cancer and Advanced Colorectal Adenomas
}

\author{
ANDRA IULIA SUCEVEANU ${ }^{1}$, LAURA MAZILU ${ }^{1}$, CORNELIA NITIPIR ${ }^{2}$, ANCA PANTEA STOIAN²*, IRINEL PAREPA ${ }^{1}$, \\ CLAUDIA VOINEA ${ }^{1}$, ADRIAN PAUL SUCEVEANU ${ }^{1}$ \\ 'Ovidius University, Faculty of Medicine, Universitatii Str., 900470, Constanta, Romania \\ ${ }^{2}$ Carol Davila University of Medicine and Pharmacy, 8 Eroii Sanitari Str., 050474, Bucharest, Romania
}

\begin{abstract}
Interval colorectal cancer (ICRC) means CRC discovered at or before the second colonoscopy during a screening interval. Literature provides data concerning the present issue, 7.2-9\% of CRCs meeting the definition of interval CRC, without knowing the risk factors for this. We aimed to study if diabetes mellitus (DM) patients have a greater risk to develop ICRC/advanced adenomas (ACRA). We randomly included in the study 50 patients aged over 50 years old diagnosed with DM in whom colonoscopy was done for different reasons. Were excluded patients with CRC/ACRA diagnosed at first colonoscopy and results were compared to those of an age/gender-matched group of patients without DM as background. The interval of colonoscopies was fixed at 36 months (the shortest interval used for surveillance after a polypectomy). The total number of interval lesions significantly differs in our two groups $(p=0.022, q=0.17)$. Interval $C R C$, serrated adenomas and villous adenomas were more frequent in the T2D group. $(p=0.013, p=0.032$, respectively $p=0.011, q=0.14)$. DALM lesions were more frequently present in controls than in $T 2 D(p=0.049)$ Results showed that patients with interval ICRC were two times more in DM group in male gender $(p=0.003$, ss) (4 pts, respectively $2 \mathrm{pts}$ ) and 1.5 times greater in female group ( $3 \mathrm{pts}$, respectively $2 \mathrm{pts}$ ). The rate of CRC occurrence during the interval period of 36 months was $0.16 \%$ for male and $0.12 \%$ for females. Regarding the occurrence of ACRA (villous/tubulovillous adenomas), male patients with DM had 3 times more ACRA lesions than the control group ( $p=0.029$, ss) ( 9 pts vs 3 pts) while females patients with DM had 2 times more ACRA than controls ( $p=0.031$, ss) ( 6 pts vs $3 p t s)$. The rate of interval advanced CR lesions occurrence during the interval period of 36 months was $0.36 \%$ for male and $0.24 \%$ for females. DM looks be a risk factor ICRC/ACRA by accelerating the colorectal epithelial proliferation rate. Male gender looks to be more exposed to ICRC/ACRC, especially when they are diagnosed with metabolic co-morbidities like T2D.
\end{abstract}

Keywords: interval, colorectal cancer, diabetes mellitus

Despite the benefits that global screening procedures bring to a significant decline of CRC epidemiologic rates in the last decades, this type of cancer remains still a major cause of mortality worldwide. [1, 2]. The 5-year survival rate for incipient CRC at the time of diagnosis is around $90 \%$, while in distant metastasis cancer the survival rate at five years is smaller than $10 \%$ [3]. Screening procedure using colonoscopy is effective in preventing CRC occurrence, with a remarkable decline in new cases and deaths in the last three decades. [4]. In the general population, the current screening management involves a colonoscopy at the age of 50 years, followed by one complete colonoscopy every 10 years after the first negative one. [5] Discovery of any lesion with malignant potential as villous or tubular-villous adenomatous or serrated polyps, shortens the intervals of screening and involves endoscopic therapies [6]. A three-year interval for subsequent colonoscopies is required for patients having ACRA: > 3 adenomas, adenomatous or serrated polyps, bigger than $10 \mathrm{~mm}$, villous adenomas or high-grade dysplasia, dysplasia of a traditional or serrated adenoma [6]. Adenomatous polyposis (FAP), hereditarynonpolyposis colorectal cancer syndrome (HNPCC/Lynch syndrome) and IBDs, as Crohn's Disease or ulcerative colitis, involve earlier and more frequent examinations according to the high frequency of cancer occurrence [7],[8]. Besides the detection of polyps, which are lesions visible to the necked eye and easy to remove during colonoscopy, there is the dysplasia superposed over IBD lesions, very difficult to recognize at colonoscopy, arising from flat, plaque-like, or occasionally raised polypoid lesions defined as dysplasia- associated lesion or masses (DALM) [9-11]. Literature proves that interval CRC are more frequent in these categories of patients and for this reason, the colonoscopy intervals were shortened. Other risk factors that as obesity or diabetes mellitus are still under investigation in order to detect if they can be involved in ICRC occurrence [12]. Of course, we have to take into account that examination variables can interact with the colonoscopy effectiveness, especially for the proximal colon. As a definition for interval CRC, World Endoscopy Organization (WEO) defined it as colorectal cancer diagnosed after a colorectal screening examination or test in which no cancer is detected, and before the date of the nextrecommended exam [13]. Some studies suggest that 1 of 45 CRC are the interval type and others conclude that ICRC reaches around $9 \%$ of all CRC [13-16]. Issues regarding the effectiveness of early examination in patients at risk to develop CRC are in a great manner solved, the physicians being in accordance to shorten the interval length between colonoscopies. Regarding the rest of the risk factors for CRC occurrence, literature data lack of information regarding the interval CRC occurrence [17]. On this background, we aimed to study if diabetes mellitus (DM) patients have a greater risk to develop ICRC/ACRA.

\section{Experimental part}

Material and method

It was a prospective study made during 2015-2018 in Internal Medicine Clinic of St Apostle Andrew Clinical Hospital, Gastroenterology and Diabetes Mellitus 
Departments. We randomly included in the study 50 patients, men and woman, aged over 50 years old and diagnosed with $\mathrm{DM}$, in whom colonoscopy was done for different reasons. Were excluded patients with CRC/ACRA diagnosed at firstcolonoscopy and results were compared to those of an age/gender-matched group of patients without DM as background. The interval of colonoscopies was fixed at 36 months, having as a model the interval used for significant risk factors as those mentioned above or the shortest interval used for surveillance after polypectomy. Blood samples were collected during the enrollment period from patients with T2D and controls. Glycated hemoglobin ( $\mathrm{HbAlc})$, all fractions of lipids, like cholesterol (total, HDL, LDL) and triglycerides (TG) were routinely detected. C-reactive protein (CRP) levels were obtained using ELISA technique [18-20].

\section{Statistics}

SPSSStudent Version 18.0 (Valuepack - 6th Edition) was the statistic tool for results analyze. T-Test, Fisher's test and the two-tailed $\chi^{2}$ test were used to compare different results and $p$ under the value of 0.05 was considered statistically significant. The association between ICRC/ ACRA and independent variables, including age, diet, ethnicity and other risk factors were calculated using multivariable linear regression analysis were made for both patientgroup. Pearson's correlation coefficients were used to make associations between interval CRC and laboratory

\begin{tabular}{|c|c|c|}
\hline & $\begin{array}{l}\text { T2D patients } \\
\mathrm{N}=\mathbf{5 0}, \%\end{array}$ & $\begin{array}{l}\text { Controls } \\
\mathrm{N}=\mathbf{5 0}, \\
\% \text { /intervals }\end{array}$ \\
\hline $\begin{array}{ll}\text { Gender } & \\
& \text { Males } \\
& \text { Females }\end{array}$ & $\begin{array}{l}23[46] \\
26[52]\end{array}$ & $\begin{array}{l}27[54] \\
24[48]\end{array}$ \\
\hline Age, mean & $55.82 \pm 5.66$ & $57.21 \pm 10.41$ \\
\hline $\begin{array}{l}\text { Diet type } \\
\text { Vegetarian } \\
\text { Mediterranean } \\
\text { Junk food } \\
\text { Sweets }\end{array}$ & $\begin{array}{l}4[8] \\
10[20] \\
25[50] \\
11[22]\end{array}$ & $\begin{array}{l}10[20] \\
14[28] \\
18[38] \\
8[16]\end{array}$ \\
\hline $\begin{array}{l}\text { Ethnicity } \\
\text { Romanian } \\
\text { ethnicity } \\
\text { Other }\end{array}$ & $\begin{array}{l}47[94] \\
3[6]\end{array}$ & $\begin{array}{l}45[90] \\
5[10]\end{array}$ \\
\hline $\begin{array}{l}\text { Physical activity } \\
\text { Absent } \\
\text { Mild/Moderate } \\
\text { Intense }\end{array}$ & $\begin{array}{l}30[60] \\
14[28] \\
6[12]\end{array}$ & $\begin{array}{l}20[40] \\
28[56] \\
2[4]\end{array}$ \\
\hline Familial history of T2D & $35[70]$ & $7[14]$ \\
\hline Obesity & $29[58]$ & $13[26]$ \\
\hline HbAlc (\%) & 7.6 & 4.9 \\
\hline LDL (mg/dl) & $189[111-240]$ & $96[85-116]$ \\
\hline $\mathrm{HDL}(\mathrm{mg} / \mathrm{dl})$ & $38[35-41]$ & $55[43-60]$ \\
\hline TG & $241[155-318]$ & $158[142-177]$ \\
\hline CRP (mg/dl) & $1.7[0.56-2.11]$ & $1.01[0.88-1.45]$ \\
\hline
\end{tabular}

findings (serum biomarkers, gender, age, ethnicity, physical activity, obesity and T2D according to international scales.

\section{Results and discussions}

Major demographic and clinical characteristics of patients enrolled in the study can be followed in table 1.

Total number of interval lesions significantly differs in our two groups ( $p=0.022, q=0.17$ ). Regarding different types of interval lesions, we discovered that interval CRC, serrated adenomas and villous adenomas were more frequent in T2D group. $(p=0.013, q=0.15 ; p=0.032$, $q=0.19$ respectively $p=0.011, q=0.14$ ). DALM lesions were more frequent present in controls than in $\mathrm{T} 2 \mathrm{D}(p=0.036$, $q=-0.22$ ) (table 2).

Correlation between different types of ICRC/ACRA and laboratory findings in T2D patients.

We made correlations between ICR lesions with the laboratory findings of $\mathrm{T} 2 \mathrm{D}$ patients and we detected positive associations with increasing number of ICRC and some ACRC (serrated adenomas villous adenomas and DALM lesions) and increased levels of HbAlc, LDL cholesterol, TG and inflammatory markers such as CRP and ESR, beside of gender, age, ethnicity or other personal characteristics (table 3).

Results showed that patients with ICRC were 2 times more in DM group in male gender ( $p=0.003, s s)$ ( $4 \mathrm{pts,}$ respectively $2 \mathrm{pts}$ ). The rate of CRC occurrence during
Table 1

DEMOGRAPHIC AND CLINICAL CHARACTERISTICS OF PATIENTS AND CONTROLS ENROLLED IN THE STUDY 


\begin{tabular}{|l|l|l|l|l|}
\hline \multirow{2}{*}{ Interval CR lesions } & \multicolumn{4}{|c|}{ Patients } \\
\cline { 2 - 5 } & T2D & Controls & $p$-value & $q$ \\
\hline ICRC & 6 & 2 & 0.013 & 0.15 \\
Serrated adenomas & 5 & 2 & 0.032 & 0.19 \\
Villous adenomas & 7 & 1 & 0.011 & 0.14 \\
Tubulo-villous adenomas & 3 & 3 & 0.341 & 1.01 \\
DALM & 3 & 5 & 0.036 & -0.22 \\
Total & 24 & 13 & 0.022 & 0.17 \\
\hline
\end{tabular}

Table 2

INTERVAL CR LESIONS IN T2D PATIENTS AND CONTROL

Table 3

MULTIVARIABLE LINEAR REGRESSION ANALYSIS FOR CORRELATION BETWEEN LABORATORY FINDINGS AND DIFFERENT INTERVAL COLORECTAL LESIONS IN T2D

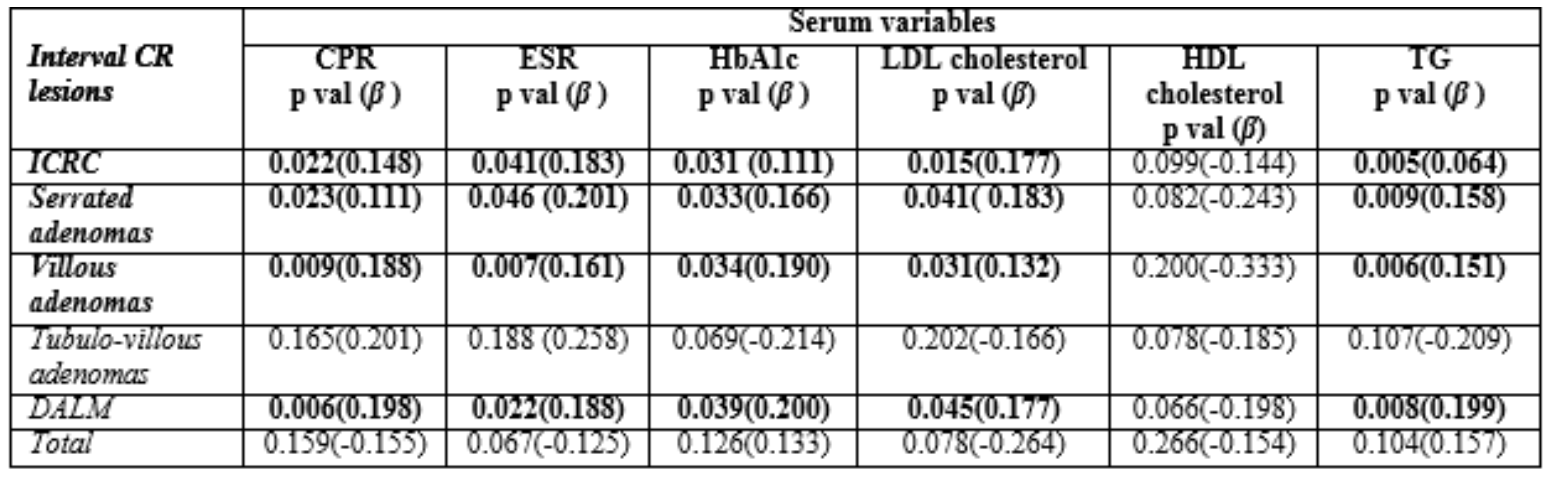

interval period of 36 months was $0.16 \%$ for male and $0.12 \%$ for females. Regarding occurrence of ACRA (villous/tubulovillous adenomas), male patients with DM had 3 times more ACRA lesions than control group ( $p=0.029$, ss) ( 9 pts vs 3 pts) while females patients with DM had 2 times more ACRA than controls ( $p=0.031$, ss) ( 6 pts vs $3 p t s$ ). The rate of ACRA occurrence during interval period of 36 months was $0.36 \%$ for male and $0.24 \%$ for females.

Interval CRC and premalignant lesions became an important concern between gastroenterologists and endoscopists, the intervals between two colonoscopies during the screening program being important issues. [15] Some researchers $[1,14]$ concluded that 1 in 13 CRCs may be interval or missed CRCs from 4883 examined cases while others suggest that 1 in 45 of CRCs are of the interval type $[1,16]$. Several studies relate an incidence rate of interval CRC around $9 \%$, butdifferent according to different sites of CR lesions along the CR tract [13]: 4615 proximal interval CRCs out of 53847 total proximal CRCs and 2726 distal interval CRCs out of a total 77922 distal CRCs [16]. This analysis concluded that 1 of 15 proximal CRCs and 1 in 34 distal CRCs are interval type [14], Proximal interval CRCs are 2.4 times more common compared to distal interval CRCs [21]. In our study, 6 of 50 patients (12\%) with diabetes mellitus had interval CRC, while 2 of controls (4\%) had the same pathology, with a mean of $8 \%$ for the whole group of enrolled patients. Our study showed that the global incidence rate of interval CRC is not significantly different from other studies ( $8 \%$ compared to $9 \%$ reported by Sanduleanu etal.) [13]. Still, diabetes mellitus proved that is significantly involved in interval CRC occurrence, compared to controls $(p=0.013)$. Regarding the ACRL, literature data [22] report that 31 of 842 patients with tubulovillous adenomas, specifically of the rectosigmoid, possibly incompletely excised became interval CRCS. Other meta-analysis showed that 58 patients of 9167 ACRA patients were diagnosed with CRC in less than four years [23] and $75 \%$ of them were probably missed lesion or incomplete endoscopic adenoma resection.

\section{Conclusions}

DM seems to be a risk factor ICRC and ACRA like serrated adenomas, villous and DALM lesions by accelerating the colorectal epithelial proliferation rate. Male gender looks to be more exposed to ICRC/ACRC, especially when they are diagnosed with metabolic co-morbidities like T2D.

\section{References}

1.BENEDICT, M., NETO, A.G., ZHANG, X., World J Gastroenterol, 21, no. 45,2015, p.12735.

2.SIEGEL, R.L., MILLER, K.D., JEMAL, A., CA Cancer J Clin, 65, 2015, p.5-29.

3.RICHTER, J.M., CAMPBELL, E.J., CHUNG, D.C., Clin Colorectal Cancer, 14, 2015, p.46.

4.ALLEN, J.., Curr Gastroenterol Rep.,17,2015,p.10.

5.WINAWER, S., FLETCHER, R., REX, D., BOND, J., BURT, R., FERRUCCI, J., GANIATS, T., LEVIN, T., WOOLF, S., JOHNSON, D., ET AL., Gastroenterology, 124, 2003, p.544.

6.SHORT, M.W., LAYTON, M.C., TEER, B.N., DOMAGALSKI, J.E., Am Fam Physician, 91, 2015, p. 93.

7.BALACEANU, A., DIACONU, C., MATEESCU, D., STANICA, A. Medical Ultrasonography, 12, no. 4, 2010, pp. 345-348.

8.STANCIU, A.E, ANTON, A., ZAMFIR C., STANCIU, M.M., et al.Romanian Biotechnological Letters.,22,no. 2,2017p.12419-12426.

9.MATTAR, M.C., LOUGH, D., PISHVAIAN, M.J., CHARABATY, A., Gastrointest Cancer Res., 4, 2011, p.53.

10.BALACEANU, A., DIACONU, C., ARON, G. Medical Ultrasonography, 16, no. 2, 2014, pp. 172-174.

11.ARDELEANU V., FRINCU,L.L., NECHITA,A., GEORGESCU,C., Rom J Morphol Embryol,55, no.2,2014,p.319-323.

12.DIACONU, C., NASTASA, A., ZAKI, A.R., ARSALAN, M. The 2nd International Conference on Interdisciplinary Management of Diabetes Mellitus and its Complications - Diabetes mellitus as cardiovascular disease, INTERDIAB 2016 Proceedings, 2016, pp 201-210. Ed. Niculescu. Editors Cristian Serafinceanu, Octavian Negoita, Viviana Elian.

13.SANDULEANU, S., LE CLERCQ, C.M., DEKKER, E., MEIJER, G.A., RABENECK, L., RUTTER, M.D., VALORI, R., YOUNG, G.P., SCHOEN, R.E., Gut, 64,2015, p.1257.

14.SINGH, H., NUGENT, Z., DEMERS, A.A., BERNSTEIN, C.N., Am J Gastroenterol., 105, 2010, p. 2588-2596. 
15.GAVRILA, R., ISAILA, M.,MIRCIOIU, C.,et al.Farmacia, 66, no. 6,2018,p.930-937

16.SANDULEANU, S., MASCLEE, A.M., MEIJ ER, G.A., Nat Rev Gastroenterol Hepatol, 9, 2012, p.550.

17.DIACONU, C., BALACEANU, A., COSTACHE, C. Journal of Hepatology, 60, Supplement 1, 2014, S515.

18.MARCU, D., SPINU, D.,MISCHIANU, D., SOCEA, B., OPREA, I., BRATU, O., Romanian Journal Of Military Medicine,120, no. 3, 2017, p. 39-42.

19.POPESCU, R., BRATU, O., SPINU, D., MARCU, D., FARCAS, C., DINU, M., MISCHIANU, D. Romanian Journal of Military Medicine, 118, no. 3, 2015, p. 16-19.
20.NICOLAE, I.,TAMPA, M.,MITRAN, C.,et al.,FARMACIA,65,2017 no.4,p.617.

21.SINGH, S., SINGH, P.P., MURAD, M.H., SINGH, H., SAMADDER, N.J., Am J Gastroenterol., 109, 2014, p.1375.

22.ATKIN, W.S., MORSON, B.C., CUZICK, J., N Engl J Med., 326, 1992, p.658-662.

23.ROBERTSON, D.J ., LIEBERMAN, D.A., WINAWER, S.J ., AHNEN, D.J ., BARON, J.A., SCHATZKIN, A., CROSS, A.J ., ZAUBER, A.G., CHURCH, T.R., LANCE, P., ET AL., Gut, 63, 2014, p.949.

$\overline{\text { Manuscript received: } 7.09 .2018}$ 